\title{
Effects of feeding rapeseed oil, soybean oil, or linseed oil on stearoyl-CoA desaturase expression in the mammary gland of dairy cows
}

\author{
A. A. A. Jacobs, ${ }^{1}$ J. van Baal, ${ }^{\star}$ M. A. Smits, $†$ H. Z. H. Taweel,‡ W. H. Hendriks, ${ }^{\star}$ A. M. van Vuuren, ${ }^{*}$ \\ and J. Dijkstra* \\ ${ }^{*}$ Animal Nutrition Group, Wageningen University, PO Box 338, $6700 \mathrm{AH}$ Wageningen, the Netherlands \\ †Animal Breeding and Genomics Centre, Wageningen UR Livestock Research, PO Box 65, 8200 AB Lelystad, the Netherlands \\ $\neq C C L$ Research, N.C.B.-laan 52, 5462 GE Veghel, the Netherlands
}

\section{ABSTRACT}

Stearoyl-CoA desaturase (SCD) is an important enzyme in the bovine mammary gland, and it introduces a double bond at the $\Delta^{9}$ location of primarily myristoyl-, palmitoyl-, and stearoyl-CoA. The main objective of this study was to compare the effects of various fatty acids (FA) typically present in dairy cow rations on the expression of SCD1 and SCD5 in the mammary gland of dairy cows. Twenty-eight Holstein-Friesian cows were randomly assigned to 1 of 4 dietary treatments. The dietary treatments were a basal diet supplemented (dry matter basis) with $2.7 \%$ rapeseed oil as a source of C18:1 cis- $9 ; 2.7 \%$ soybean oil as a source of C18:2 cis9,12; $2.7 \%$ linseed oil as a source of $\mathrm{C} 18: 3$ cis-9,12,15; or $2.7 \%$ of a $1: 1: 1$ mixture of the 3 oils. The oil supplements were included in the concentrate, which was fed together with corn silage and grass silage. In addition, cows were grazing on pasture, consisting mainly of perennial ryegrass, during the day. Biopsies from the mammary gland were taken and analyzed for mRNA expression of SCD1 and SCD5 by using quantitative real-time PCR. Milk yield as well as milk protein and fat contents did not differ among the 4 dietary treatments. Dietary supplementation with rapeseed oil and linseed oil increased proportions of C18:1 cis-9 and C18:3 cis$9,12,15$ in blood plasma, respectively, compared with the other treatments. Supplementation with soybean oil and linseed oil increased milk FA proportions of C18:2 cis-9,12 and C18:3 cis-9,12,15, respectively, but supplementation with rapeseed oil did not increase C18:1 cis-9 in milk. Mammary SCD1 expression was reduced by supplementation of soybean oil compared with rapeseed oil and linseed oil. In contrast, SCD5 expression did not differ among the 4 treatments. The C16 and C18 desaturation indices, representing proxies for SCD activity, were lower for the soybean oil diet compared with the diet supplemented with a mixture

Received June 7, 2010.

Accepted October 14, 2010.

${ }^{1}$ Corresponding author: antoon.jacobs@wur.nl of the 3 oils. In conclusion, our study shows that mammary SCD1 expression is significantly downregulated in dairy cows by feeding unprotected soybean oil compared with rapeseed oil or linseed oil, and this is partially reflected by the lower desaturase indices in the milk. Furthermore, mammary SCD5 expression appears to be differently regulated than expression of SCD1.

Key words: stearoyl-CoA desaturase (SCD), dairy cow, mammary gland, milk fatty acid

\section{INTRODUCTION}

The relationship between dietary fat type and various chronic diseases in humans, including cardiovascular disease, has been extensively investigated. Although various trans fatty acids (TFA) have an unfavorable effect on the serum lipoprotein profile, conjugated linoleic acids (CLA) have anticarcinogenic and antiatherogenic effects (Lock and Bauman, 2004). Saturated fatty acids (SFA) generally increase serum total and low-density lipoprotein cholesterol levels and increase the risk of cardiovascular disease (Mensink et al., 2003). Moreover, high intake of SFA is related to reduced insulin sensitivity and subsequently to increased type 2 diabetes (Parillo and Riccardi, 2004). Decreasing the proportion of SFA in milk fat may therefore be beneficial for human health. In the Netherlands, however, the content of even-chain SFA in milk fat of raw bovine milk was higher in 2005 compared with 1992, which was related to changes in composition of diets fed to dairy cattle (Heck et al., 2009).

Stearoyl-CoA desaturase (SCD) converts SFA into monounsaturated fatty acids (MUFA) by introducing a double bond between carbon atoms 9 and 10 in the saturated carbon chain, but it can also catalyze the desaturation of a wide spectrum of monounsaturated fatty acyl-CoA substrates, including C18:1 trans-11 to generate cis-9, trans-11 CLA (Ntambi and Miyazaki, 2004). Increasing SCD activity is therefore of interest to increase the content of various beneficial fatty acids (FA) in milk. In lactating ruminants, stearoyl-CoA desaturase 1 (SCD1) is abundantly expressed in the 
mammary gland and plays an important role in the production of milk fat (McDonald and Kinsella, 1973; Bernard et al., 2008; Bionaz and Loor, 2008). Recently, a novel isoform of SCD, designated stearoyl-CoA desaturase 5 (SCD5), has been identified, which appears to be expressed predominantly in brain and pancreas (Wang et al., 2005; Lengi and Corl, 2007). StearoylCoA desaturase 5 is also expressed in the bovine mammary gland (Gervais et al., 2009), but the contribution of SCD5 to mammary SCD activity during lactation and whether its expression can be influenced by dietary FA remains obscure.

Nutritional regulation of SCD1 expression has been extensively studied in rodents, primarily in liver and adipose tissue (Ntambi, 1999), and to a smaller degree in the mammary gland (Lin et al., 2004; Singh et al., 2004). It is well established that polyunsaturated FA (PUFA) supplementation, both $\mathrm{n}-3$ and $\mathrm{n}-6$, results in severe downregulation of SCD1 in both liver and adipose tissue of rodents, whereas SFA and MUFA have little effect (Ntambi, 1999). In dairy cows, only a few studies have examined the effect of nutritional factors on regulation of SCD in the mammary gland (Bernard et al., 2008). Therefore, knowledge regarding the effect of nutrition on milk fat synthesis in the bovine mammary gland and especially the underlying mechanisms, such as regulation of key lipogenic genes, is still limited. Most of the studies that examined the effect of nutritional factors on mammary SCD in dairy cows, used diets that cause milk fat depression (MFD). Harvatine and Bauman (2006) and Peterson et al. (2003) both reported a tendency toward reduction of mammary SCD1 expression in dairy cows with diet-induced MFD. Addition of fish oil to the diet of dairy cows, which also causes MFD, resulted in a significant reduction of SCD1 mRNA in the mammary gland (Ahnadi et al., 2002). Nevertheless, the effects of the major unsaturated FA C18:1 cis-9, C18:2 cis-9,12, or C18:3 cis-9,12,15, which are typically present in dairy cow rations, on mammary SCD1 and SCD5 expression is not clear. Consequently, in the present study we investigated the effects of dietary FA supplementation of $\mathrm{C} 18: 1$ cis-9, C18:2 cis-9,12, or C18:3 cis-9,12,15, by feeding unprotected rapeseed oil, soybean oil, or linseed oil, respectively, or a mixture of the 3 oils, on expression of both SCD1 and SCD5 in the mammary gland of dairy cows and evaluated the effects of these FA on milk desaturation indices as indicators of mammary SCD activity.

\section{MATERIALS AND METHODS}

\section{Animals and Diets}

This experiment was conducted at the Cranendonck Research Farm, the Netherlands, between September 26 and November 14, 2007. Twenty-eight Holstein-Friesian cows were distributed to ensure uniform distribution among 7 blocks based on parity $(2.4 \pm 0.63)$, DIM (153 $\pm 32.8 \mathrm{~d})$, milk yield $(25.7 \pm 3.08 \mathrm{~kg} / \mathrm{d})$, and milk fat content $(4.31 \pm 0.12 \%$; all values expressed as mean \pm SEM). Cows within each block were randomly assigned to 1 of 4 dietary treatments $(\mathrm{n}=7$ per dietary treatment). The dietary treatments were a basal diet supplemented (DM basis) with $2.7 \%$ rapeseed oil (RO) as a source of C18:1 cis-9; 2.7\% soybean oil (SO) as a source of $\mathrm{C} 18: 2$ cis-9,12; $2.7 \%$ linseed oil (LO) as a source of C18:3 cis-9,12,15; or $2.7 \%$ of a $1: 1: 1$ mixture of the 3 oils (MIX). Oil supplements were not protected against biohydrogenation in the rumen. The oil supplements were included in the concentrate, which was fed together with corn silage and grass silage as a mixed ration (MR). Corn silage, grass silage, and concentrates comprised 52, 12 , and $36 \%$ of the MR, respectively, on a DM basis. In addition to the MR, the cows received approximately 1 $\mathrm{kg}$ of a commercial standard concentrate per day through automatic feeding stations. Cows were milked twice daily at 0600 and $1800 \mathrm{~h}$ and grazed on pasture from 0800 until $1600 \mathrm{~h}$. At other times, cows were inside a freestall barn and had ad libitum access to the MR. The pasture used for grazing was established in September 2006 and consisted primarily of ryegrass (Lolium perenne L.) with approximately $20 \%$ white clover (Trifolium repens L.). The paddocks were approximately 5 ha and the total stocking density was 16 cows/ha. The treatment period lasted $23 \mathrm{~d}$; after the treatments ended, cows were fed a posttrial diet (POST) without oil supplementation for a period of $28 \mathrm{~d}$ as control. In the posttrial period no concentrate was present in the MR as all the concentrate was provided through automatic feeding stations. Ingredient and chemical composition of the different concentrates are presented in Table 1, and chemical and FA composition of the pasture and of the different MR used in this experiment are presented in Table 2. Individual milk production and MR intake per treatment group were recorded daily. Pasture intake was estimated from the difference between grass height measurements made before and after grazing, assuming that grass growth during the period of grazing was a negligible proportion of total grass consumption, given the short grazing period length and stocking density (Penning, 2004). Sward surface height was measured as described in Abrahamse et al. (2008a) using 40 sward surface height measurements per averaged height observation.

\section{Sampling and Analysis}

Representative samples of individual feedstuffs including pasture and of the MR were taken during the last $3 \mathrm{~d}$ of the treatment and posttrial periods. 
Table 1. Ingredient and chemical composition of the concentrate fed posttrial (POST) and the concentrates supplemented with rapeseed oil (RO), soybean oil (SO), or linseed oil (LO), or a mixture of these oils (MIX)

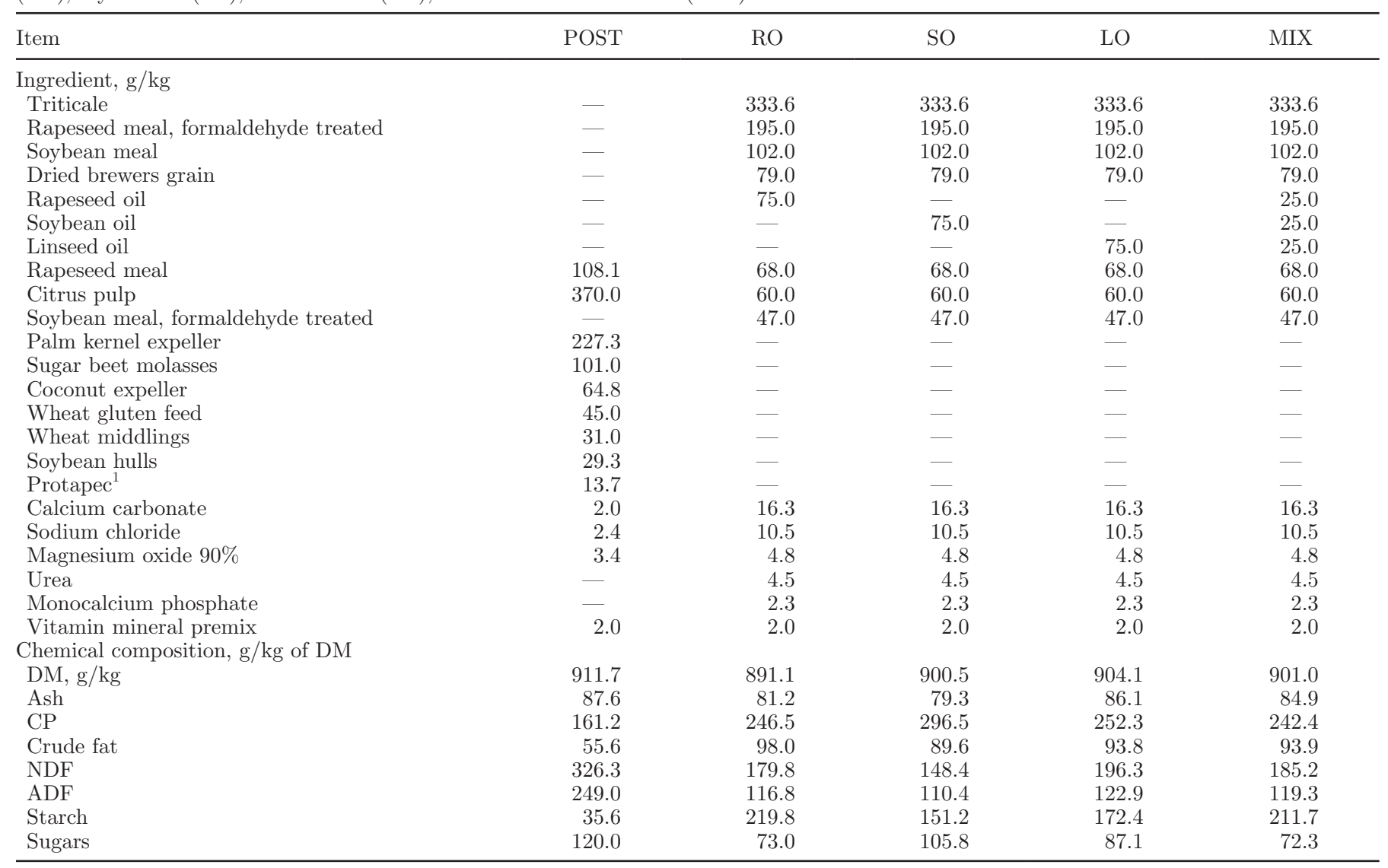

${ }^{1}$ Potato fruit-juice (concentrated) mixed with soybean hulls (Cehave Landbouwbelang, Veghel, the Netherlands).

All feed samples were freeze-dried, ground to pass a 1-mm screen, and analyzed for DM, ash, CP, crude fat, $\mathrm{NDF}$, ADF, starch, sugars, and FA composition. The $\mathrm{DM}$ content was determined by drying at $103^{\circ} \mathrm{C}$ (ISO 6496; ISO, 1999a) and ash content was determined by combustion at $550^{\circ} \mathrm{C}$ (ISO 5984; ISO, 2002). Crude protein $(6.25 \times \mathrm{N})$ was determined by using the Kjeldahl method (ISO 5983; ISO, 2005), and crude fat was determined by using the Berntrop method with acid hydrolysis (ISO 6492; ISO, 1999b). Neutral detergent fiber was determined according to a modified method of Van Soest et al. (1991) with additional incubations in $\alpha$ amylase and protease as described by Goelema et al. (1998). Acid detergent fiber was determined according to Van Soest (1973). Starch was analyzed using enzymatic hydrolysis (ISO 15914; ISO, 2004), and sugar analysis was carried out using a $40 \%$ ethanol solution as described by Abrahamse et al. (2008b).

For FA analysis of the feedstuffs, fat from freeze-dried samples was extracted with chloroform-methanol (2:1 $\mathrm{vol} / \mathrm{vol}$ ), according to Folch et al. (1957) with minor modifications as described by Khan et al. (2009), except that no internal standard was added. Methylation of FA was done as follows: extracted fat was dissolved in 2 $\mathrm{mL}$ of hexane, and $100 \mathrm{mg}$ of anhydrous sodium sulfate was added. Next, $50 \mu \mathrm{L}$ of a $30 \%$ sodium methanolate solution in methanol was added to transesterify the glycerides to their corresponding methyl esters by vortexing for 2 min. at room temperature. Subsequently, 1 $\mathrm{mL}$ of hydrochloric acid in methanol solution $(1.25 \mathrm{M})$ was added to esterify the free FA, followed by heating the mixture for $20 \mathrm{~min}$ at $85^{\circ} \mathrm{C}$ under constant shaking. The mixture was then cooled to room temperature under a flow of cold water and shaken vigorously; 1 $\mathrm{mL}$ of the upper layer, which contains the FA methyl esters, was transferred to a $1.5-\mathrm{mL}$ vial and used for GC analysis.

On the last day of the treatment period and of the posttrial period, 2 consecutive milk samples (a.m. and p.m. milkings) were obtained and pooled (1:1 ratio) for analysis. One aliquot was stored at $4^{\circ} \mathrm{C}$ pending fat, protein, and lactose analysis using mid-infrared spectrometry (ISO 9622; ISO, 1999c; Qlip NV, Zutphen, the Netherlands). The other aliquot was stored 
Table 2. Chemical composition, fatty acid composition, and DMI of the pasture used for grazing, the mixed ration used as posttrial diet (POST) and the 4 mixed rations supplemented with rapeseed oil (RO), soybean oil (SO), or linseed oil (LO), or a mixture of these 3 oils (MIX)

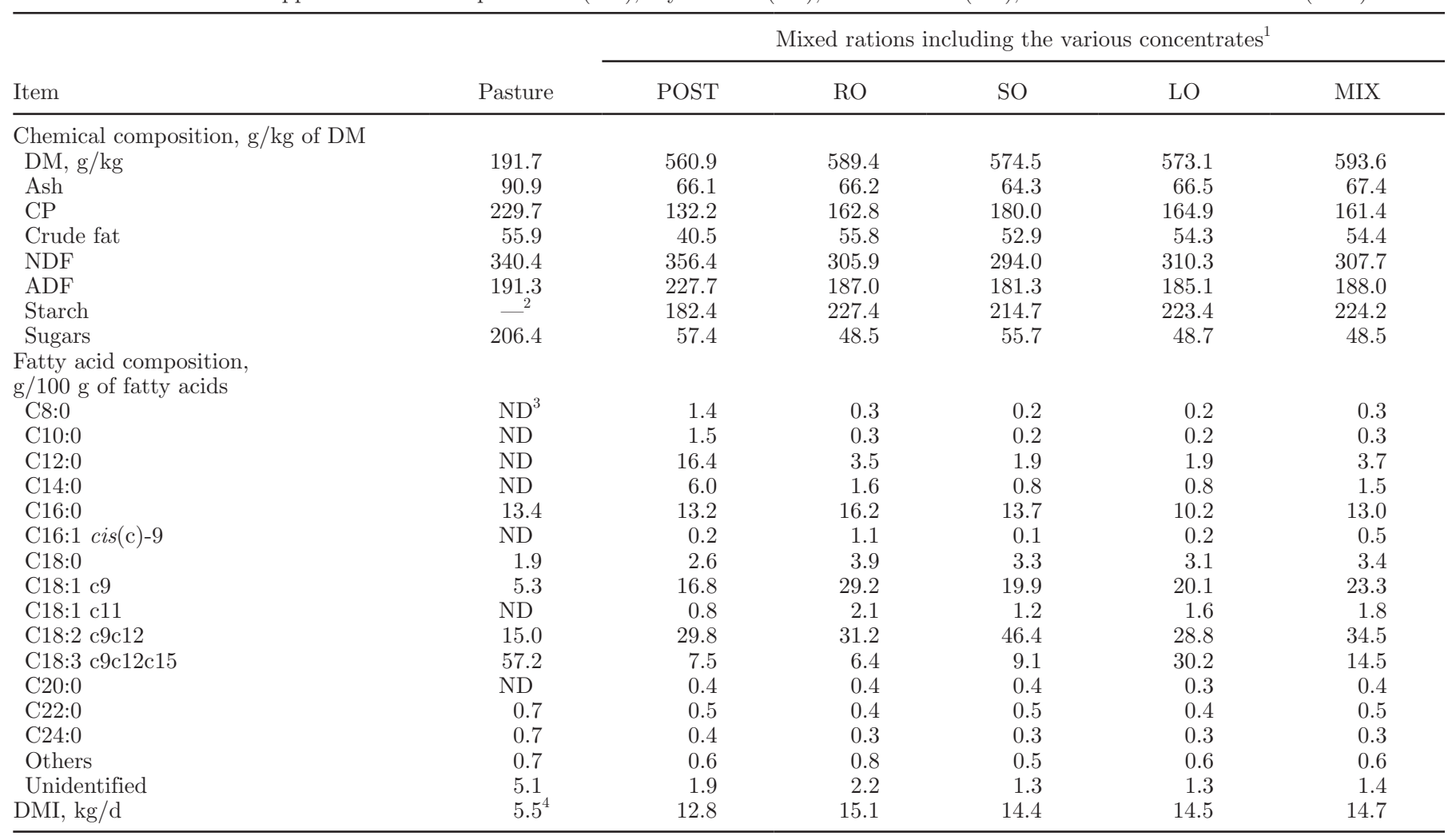

${ }^{1}$ Including concentrate that was supplied through the automatic feeding stations.

${ }^{2}$ Not determined.

${ }^{3} \mathrm{ND}=$ not detected.

${ }^{4} \mathrm{DMI}$ of pasture was $5.5 \mathrm{~kg} / \mathrm{d}$ during the 4 dietary treatments and was $4.8 \mathrm{~kg} / \mathrm{d}$ during POST.

at $-20^{\circ} \mathrm{C}$ pending $\mathrm{FA}$ analysis. Milk FA extraction and methylation were performed as described by van Knegsel et al. (2007) with some minor adjustments. First, the milk samples were heated to $45^{\circ} \mathrm{C}$ and a representative milk sample of $20 \mathrm{~mL}$ was centrifuged at $3,000 \times g$ for $10 \mathrm{~min}$ at $4^{\circ} \mathrm{C}$. The upper fat layer was then collected with a spatula, dried on filter paper, and transferred to a $1.5-\mathrm{mL}$ tube, which was stored overnight at $-20^{\circ} \mathrm{C}$. Next, the milk fat samples were heated for $10 \mathrm{~min}$ at $60^{\circ} \mathrm{C}$, followed by centrifugation at 20,000 $\times g$ for 5 min at $20^{\circ} \mathrm{C}$, and the clear fat fraction was transferred to a new $1.5-\mathrm{mL}$ tube containing a small amount of anhydrous sodium sulfate. Afterward, the milk fat samples were stored at $-20^{\circ} \mathrm{C}$ until analysis. Before analysis, the frozen samples were heated for 10 min at $60^{\circ} \mathrm{C}$, followed by centrifugation at 20,000 $\times g$ for $5 \mathrm{~min}$ at $20^{\circ} \mathrm{C}$. Subsequently, $50 \mu \mathrm{L}$ of milk fat was added to $5 \mathrm{~mL}$ of hexane, and the glycerol-bound $\mathrm{FA}$ were transesterified to methyl esters by vortexing with $100 \mu \mathrm{L}$ of sodium methanolate in methanol (30\%). The solution was neutralized with $1 \mathrm{~g}$ of sodium hydrogen sulfate and dried with anhydrous sodium sulfate. This solution was then transferred to a $1.5-\mathrm{mL}$ vial and used for GC analysis.

For plasma FA analysis, blood samples $(10 \mathrm{~mL})$ were collected from the jugular vein in heparin-containing tubes at the last day of the treatment and the posttrial periods. The blood samples were centrifuged at 3,000 $\times g$ for 15 min to harvest the plasma, which was stored at $-20^{\circ} \mathrm{C}$ pending $\mathrm{FA}$ analysis. Fat was extracted using chloroform:methanol $(2: 1, \mathrm{vol} / \mathrm{vol})$ as described by Folch et al. (1957). The extracted fat was saponified using methanolic sodium hydroxide, and the constituent FA were converted into their methyl esters using boron trifluoride in methanol according to Metcalfe et al. (1966) with minor modifications as described by Khan et al. (2009).

Methylated FA obtained from feed samples, milk samples, and blood plasma samples were quantified using a gas chromatograph (Trace GC Ultra, Thermo Electron Corp., Waltham MA) equipped with a flameionization detector and auto-sampler. Methylated FA were separated using a fused-silica capillary column $(100 \mathrm{~m} \times 0.25 \mathrm{~mm}$ and $0.2 \mu \mathrm{m}$ film thickness; Restek 
RT-2560, Restek, Bellefonte, PA) using helium as a carrier gas at a constant flow of $1.5 \mathrm{~mL} / \mathrm{min}$. Methylated FA samples of $1 \mu \mathrm{L}$ were injected into the GC with a split ratio of 1:50. The following program was used for the GC: starting temperature $140^{\circ} \mathrm{C}$ for $4 \mathrm{~min}$, followed by an increase at a rate of $4^{\circ} \mathrm{C}$ per min until $240^{\circ} \mathrm{C}$ and held for $20 \mathrm{~min}$ at $240^{\circ} \mathrm{C}$. Temperature of the flameionization detector was $280^{\circ} \mathrm{C}$. Peaks were identified by comparing the retention times with those of the corresponding FA methyl ester standards (S37, Supelco, Poole, Dorset, UK) and, when no commercial standard was available, by using published chromatograms obtained under comparable analytic conditions (Loor et al., 2004; Shingfield et al., 2006; Cruz-Hernandez et al., 2007). Under these conditions, several C18:1-trans isomers were not completely resolved and are therefore listed together. Fatty acid desaturation indices in milk, as proxies for SCD activity in the mammary gland, were calculated as the ratio between the product and the sum of the product and substrate FA (Kelsey et al., 2003).

\section{Biopsy Procedure}

On the last day of the treatment and the posttrial period, approximately 0.7 to $1.0 \mathrm{~g}$ of mammary tissue was obtained from each cow by surgical biopsy from the midpoint section of a rear quarter, according to the method of Farr et al. (1996). Collected tissues were immediately snap-frozen in liquid nitrogen and stored at $-80^{\circ} \mathrm{C}$ until RNA extraction. Following biopsy, a single intramammary injection of antibiotics (Avuloxil; active ingredients: amoxicillin and clavulic acid; Pfizer Animal Health, Capelle a/d IJssel, the Netherlands) was applied in the affected rear quarter. In addition, cows received an intramuscular injection of antibiotics (Excenel, active ingredient: ceftiofur hydrochloride; Pfizer Animal Health). Cows were subsequently machine milked as normal and hand-stripped as needed to remove all intramammary blood clots. No mammary infections were observed after biopsy. The biopsy procedure was approved by the Animal Care and Ethics Committee of Wageningen UR Livestock Research (Lelystad, the Netherlands).

\section{RNA Isolation and Real-Time PCR}

Total RNA was extracted from mammary gland biopsies with Trizol reagent (Invitrogen, Breda, the Netherlands). First-strand cDNA synthesis was performed from $1 \mu \mathrm{g}$ of total RNA using Superscript III reverse transcriptase (200 units, Invitrogen), dNTPs (0.5 mM, Roche Diagnostics, Almere, the Netherlands), and random hexamer primers (250 ng, Roche Diagnos- tics) in a volume of $20 \mu \mathrm{L}$ at $50^{\circ} \mathrm{C}$ for $1 \mathrm{~h}$. Quantitative real-time PCR was performed on a LightCycler 1.2 by using FastStart DNA Master SYBR Green I reagents (Roche Diagnostics) according to the manufacturer's protocol. The following gene-specific primers were used: for SCD1, forward primer 5'-GGCGTTCCAGAATGACGTTT-3' and reverse primer 5'-AAAGCCACGTCGGGAATTG-3'; for SCD5, 5'-GGCACCGGCAGGACATC-3' (forward) and 5'-GAGCAGTCAGGAGGAAGCAGAA-3' (reverse); 18S RNA and $\beta$-actin (ACTB) were measured to correct for the input of cDNA. For $18 \mathrm{~S}$ RNA, we used the forward primer 5'-AGAAACGGCTACCACATCCAA-3' and reverse primer 5'-GGGTCGGGAGTGGGTAATTT-3'. For ACTB, 5'-GCCCTGAGGCTCTCTTCCA-3' (forward) and 5'-CGGATGTCGACGTCACACTT-3' (reverse). All primer pairs, except for $18 \mathrm{~S}$ RNA, were designed in such a way that they span an intron of their corresponding genomic sequence or that the sense or reverse primer anneals on an exon-intron junction. Templates were amplified after a preincubation for $10 \mathrm{~min}$ at $95^{\circ} \mathrm{C}$, followed by amplification for 40 cycles $\left(10 \mathrm{~s}\right.$ at $95^{\circ} \mathrm{C}$, $5 \mathrm{~s}$ at $60^{\circ} \mathrm{C}, 5 \mathrm{~s}$ at $72^{\circ} \mathrm{C}$ ). Efficiencies of PCR were established to be $100 \%$ for SCD1 and SCD5, and $95 \%$ for the 2 reference genes (18S RNA and ACTB). All reactions revealed a single product as determined by melting curve analysis. Specificity of the primer sets were verified by sequencing of the generated amplicons. Expression levels of SCD1 and SCD5 were normalized using the geometric mean of $18 \mathrm{~S}$ and ACTB. The relative RNA expression levels were calculated using the modified comparative cycle threshold (CT) method (Pfaffl, 2001). All measurements were performed in duplicate.

\section{Statistical Analysis}

Statistical analyses were carried out by ANOVA using the PROC MIXED procedure of SAS (version 9.1, SAS Institute Inc., Cary, NC) for a randomized block design. Covariate analysis using the posttrial data did not improve the ability to detect differences due to treatment and therefore, posttrial data were not included in the statistical analysis. Treatment effects on animal performance, milk FA composition, blood plasma FA composition, and mRNA abundance of the different genes were analyzed and considered significant at a probability of $P<0.05$, and as a trend at a probability of $P<0.10$. To test pairwise comparisons, post hoc analyses were carried out on the least squares means adjusted for multiple comparisons using the Tukey-Kramer test. The regression procedure (PROC REG) of SAS was used to analyze correlations between relative abundance of mammary SCD mRNA and the 
various desaturase indices calculated from milk FA during the treatment period, and to analyze correlations between milk trans-10, cis-12 CLA and milk fat content as well as short- and medium-chain fatty acids (SMCFA) in milk.

\section{RESULTS}

\section{Diet Composition, Intake, and Milk Yield}

The formulation of the different diets resulted in expected high concentrations of $\mathrm{C} 18: 1$ cis- 9 , C18:2 cis9,12, and $\mathrm{C} 18: 3$ cis-9,12,15 in the $\mathrm{RO}, \mathrm{SO}$, and $\mathrm{LO}$ diets, respectively, with the MIX diet being intermediate (Table 2). Total DMI was 20.6, 19.9, 20.0, and 20.2 $\mathrm{kg} / \mathrm{d}$ for diets RO, SO, LO, and MIX, respectively, but could not be statistically evaluated because intake was not determined per individual animal. Average milk yield was 28.8 (SEM 3.0$) \mathrm{kg} / \mathrm{d}$ and did not differ $(P=$ 0.99 ) among the 4 dietary treatments. In addition, the 4 treatments did not differ in concentration as well as yield of milk fat $(P=0.19$ and $P=0.42$, respectively), protein $(P=0.36$ and $P=0.88$, respectively), or lactose $(P=0.17$ and $P=0.96$, respectively). Mean milk fat, protein, and lactose contents were 3.59 (SEM 0.26), 3.51 (SEM 0.13), and 4.40 (SEM 0.07)\%, respectively. Calculated energy balance was positive during days of milk sampling.

\section{FA Composition of Blood Plasma}

The main FA identified in blood plasma were C18:2 cis-9,12 (mean $29.4 \mathrm{~g} / 100 \mathrm{~g}$ of FA), C18:0 (mean 15.9 $\mathrm{g} / 100 \mathrm{~g}$ of FA), C18:1 cis-9 (mean $9.0 \mathrm{~g} / 100 \mathrm{~g}$ of FA), C16:0 (mean $9.0 \mathrm{~g} / 100 \mathrm{~g}$ of FA), and C18:3 cis-9,12,15 (mean $5.6 \mathrm{~g} / 100 \mathrm{~g}$ of FA). Feeding the RO diet resulted in an elevated blood plasma fraction of C16:0, C16:1 cis-9, and C18:1 cis-9 (Table 3). Cows fed the LO diet had higher plasma proportions of $\mathrm{C} 18: 3$ cis-9,12,15 compared with those fed the other diets and higher plasma proportions of $\mathrm{C} 18: 2$ trans-11, cis- 15 compared with RO and SO.

\section{Mammary SCD1 and SCD5 Expression}

Figure 1 shows the results from analysis of SCD1 and SCD5 mRNA expression in the mammary gland using quantitative real-time-PCR. Cows fed the SO diet showed significantly decreased mammary SCD1 expression, expressed as fold change compared with the corresponding control (0.45), compared with the RO (1.00) and LO diets $(1.12 ; \mathrm{SEM}=0.14 ; P=0.01)$. The SCD1 expression of cows fed the MIX diet (0.70) was in between the other diets and did not differ $(P=0.44)$ from those diets. Mammary SCD5 expression did not differ $(P=0.12)$ among the 4 dietary treatments. The average mRNA abundance of SCD1 $(1,686 \pm 174 \mathrm{pg} /$ $\mu \mathrm{L})$ was substantially higher than that of SCD5 (0.766 $\pm 0.088 \mathrm{pg} / \mu \mathrm{L})$.

\section{FA Composition of Milk}

The effects of diet on milk FA composition are presented in Table 4. Compared with those fed LO, cows fed the MIX diet had lower proportions of C6:0 in milk fat. The C16:0 fraction in milk fat was higher for RO compared with LO and MIX. Compared with those fed the RO and MIX diets, cows fed the SO diet had a higher proportion of $\mathrm{C} 18: 0$ in milk fat. The RO diet did not result in a significantly higher proportion of C18:1 cis-9. The SO treatment did result in increased proportions of $\mathrm{C} 18: 2$ cis-9,12 in milk fat compared with $\mathrm{RO}$ and LO. Compared with the other treatments, C18:3 cis-9,12,15 was increased for the LO diet. In addition, C18:2 trans-11,cis-15 was increased for LO compared with RO and SO.

The proportion of long-chain FA (LCFA) in milk fat was higher for MIX compared with RO. The SO treatment resulted in less odd- and branched-chain fatty acids (OBCFA) in the milk fat compared with $\mathrm{RO}$, primarily because of the lower proportion of C13:0 and C15:0 for SO. Total SFA was significantly lower for MIX compared with RO and SO, and total PUFA was higher for LO and MIX compared with RO. Total TFA tended to be higher for MIX compared with RO $(P=0.09)$.

The 4 calculated desaturation indices from milk FA all showed the same tendency, with numerically the lowest values for SO and the highest values for MIX. For the desaturation indices of $\mathrm{C} 16$ and $\mathrm{C} 18$, the values for SO were significantly lower compared with the MIX diet. The $r^{2}$ between the different desaturation indices ranged from 0.66 to 0.82 .

\section{Correlation Between Desaturation Indices and SCD1 and SCD5 Expression}

Figure 2a shows the correlation between the C14 desaturation index, calculated from milk FA, and mammary SCD1 expression of the cows during the treatment period $[\mathrm{C} 14$ index $=0.086( \pm 0.007)+0.058( \pm 0.017)$ $\times$ SCD1 expression; $\left.\mathrm{r}^{2}=0.35 ; P=0.002\right]$. The $\mathrm{r}^{2}$ values of the correlation between mammary SCD1 expression and the other 3 desaturation indices were $0.35(P=$ $0.002), 0.25(P=0.01)$, and $0.39(P=0.001)$ for the $\mathrm{C} 16, \mathrm{C} 17$, and $\mathrm{C} 18$ indices, respectively. Figure $2 \mathrm{~b}$ shows the correlation between the C14 desaturation index and mammary SCD5 expression of the cows during the 
Table 3. Blood plasma fatty acid composition of cows fed the posttrial diet (POST) or the treatment diets supplemented with rapeseed oil (RO), soybean oil (SO), or linseed oil (LO), or a mixture of these 3 oils (MIX)

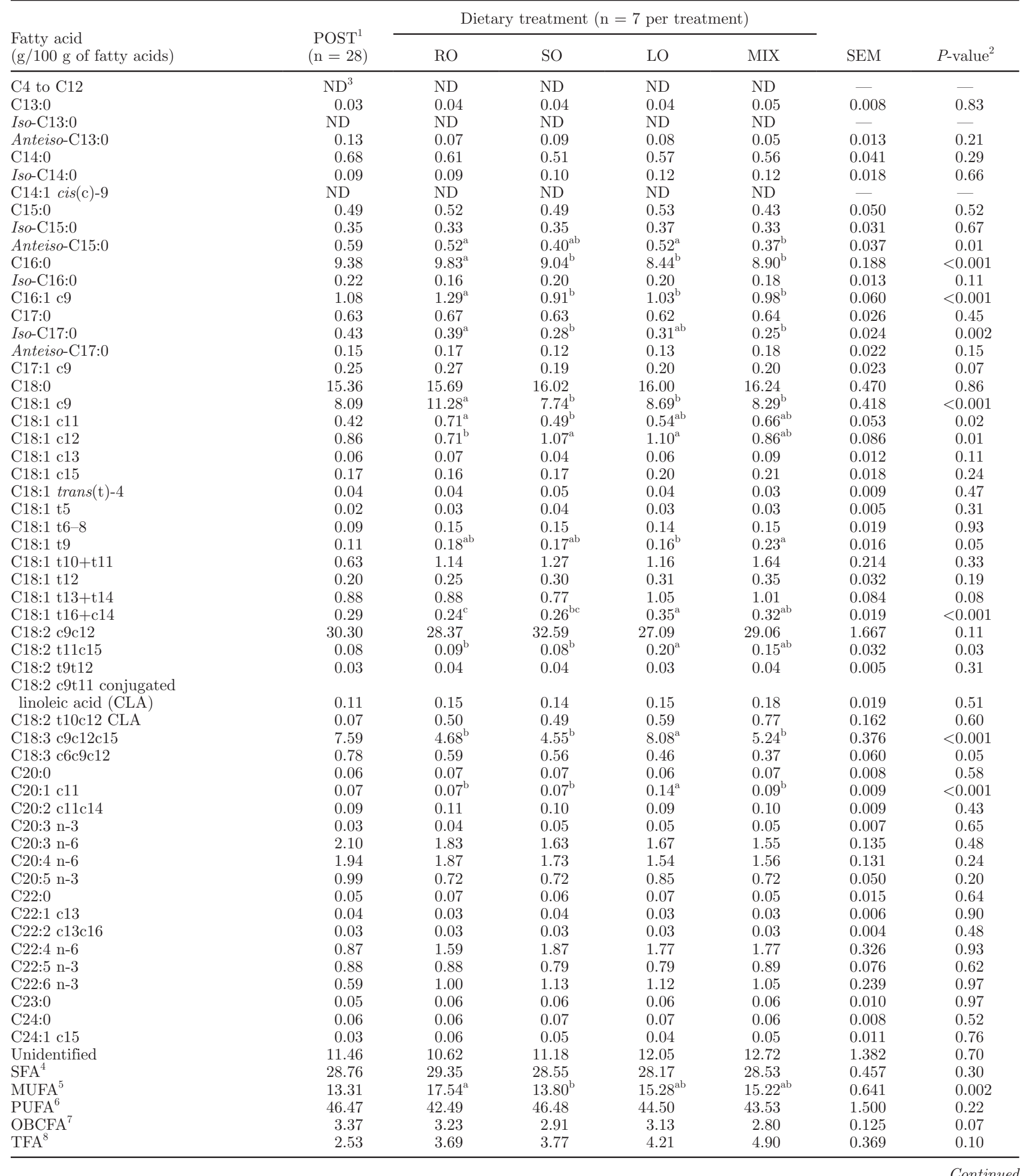


Table 3 (Continued). Blood plasma fatty acid composition of cows fed the posttrial diet (POST) or the treatment diets supplemented with rapeseed oil (RO), soybean oil (SO), or linseed oil (LO), or a mixture of these 3 oils (MIX)

${ }^{\mathrm{a}-\mathrm{c}}$ Means within a row without a common superscript differ $(P<0.05)$.

${ }^{1}$ Values are shown for comparison only and were not included in the statistical analysis.

${ }^{2}$ Effect of treatment.

${ }^{3} \mathrm{ND}=$ not detected

${ }^{4}$ Saturated fatty acids: $\Sigma(\mathrm{C} 13: 0$, iso-C13:0, anteiso-C13:0, C14:0, iso-C14:0, C15:0, iso-C15:0, anteiso-C15:0, C16:0, iso-C16:0, C17:0, iso-C17:0, anteiso-C17:0, C18:0, C20:0, C22:0, C23:0, C24:0).

${ }^{5}$ Monounsaturated fatty acids: $\Sigma(\mathrm{C} 16: 1 \mathrm{c} 9$, C17:1 c9, C18:1 c9, C18:1 c11, C18:1 c12, C18:1 c13, C18:1 c15, C18:1 t4, C18:1 t5, C18:1 t6-8, C18:1 t9, C18:1 t10+t11, C18:1 t12, C18:1 t13+t14, C18:1 t16+c14, C20:1 c11, C22:1 c13, C24:1 c15).

${ }^{6}$ Polyunsaturated fatty acids: $\Sigma$ (C18:2 c9c12, C18:2 t11c15, C18:2 t9t12, C18:2 c9t11 CLA, C18:2 t10c12 CLA, C18:3 c9c12c15, C18:3 c6c9c12, C20:2 c11c14, C20:3 n-3, C20:3 n-6, C20:4 n-6, C20:5 n-3, C22:2 c13c16, C22:4 n-6, C22:5 n-3, C22:6 n-3).

${ }^{7}$ Odd- and branched-chain fatty acids: $\Sigma$ (C13:0, iso-C13:0, anteiso-C13:0, iso-C14:0, C15:0, iso-C15:0, anteiso-C15:0, iso-C16:0, C17:0, isoC17:0, anteiso-C17:0, C17:1 c9).

${ }^{8}$ Trans fatty acids: $\Sigma(\mathrm{C} 18: 1 \mathrm{t} 4, \mathrm{C} 18: 1 \mathrm{t} 5, \mathrm{C} 18: 1 \mathrm{t} 6-8, \mathrm{C} 18: 1 \mathrm{t} 9, \mathrm{C} 18: 1 \mathrm{t} 10+\mathrm{t} 11, \mathrm{C} 18: 1 \mathrm{t} 12, \mathrm{C} 18: 1 \mathrm{t} 13+14, \mathrm{C} 18: 1 \mathrm{t} 16+\mathrm{c} 14, \mathrm{C} 18: 2 \mathrm{t} 11 \mathrm{c} 15, \mathrm{C} 18: 2$ t9t12, C18:2 c9t11 CLA, C18:2 t10c12 CLA).

treatment period [C14 index $=0.102( \pm 0.009)+0.016$ $( \pm 0.028) \times$ SCD5 expression; $\left.\mathrm{r}^{2}=0.02 ; P=0.57\right]$. The $\mathrm{r}^{2}$ values of the correlation between mammary SCD5 expression and the other 3 desaturation indices were $0.01(P=0.69), 0.02(P=0.56)$, and $0.01(P=0.57)$ for the $\mathrm{C} 16, \mathrm{C} 17$, and $\mathrm{C} 18$ indices, respectively.

\section{DISCUSSION}

The aim of this study was to compare the effects of different unprotected dietary unsaturated FA on the expression of SCD1 and SCD5 in the mammary gland of dairy cows. Therefore, we supplemented the diets of lactating cows with rapeseed oil, soybean oil, or linseed oil for a period of $3 \mathrm{wk}$ to increase the flow of $\mathrm{C} 18: 1$ cis-9, C18:2 cis-9,12, and C18:3 cis-9,12,15, respectively, to the mammary gland. The blood plasma proportions of these $3 \mathrm{FA}$ were indeed primarily related to their supply in the diet. Addition of unprotected rapeseed oil and linseed oil resulted in significantly higher blood plasma proportions of $\mathrm{C} 18: 1$ cis-9 and C18:3 cis-9,12,15, respectively. Supplementation with unprotected soybean oil did not significantly increase the proportion of $\mathrm{C} 18: 2$ cis-9,12 in blood plasma. This is probably because C18:2 cis-9,12 is the most abundant FA in blood plasma (approximately $30 \%$ of total FA) and shows considerable variation. Although the proportion of $\mathrm{C} 18: 2$ cis-9,12 in blood plasma for SO was not significantly different, the proportion of C18:2 cis-9,12 in milk fat was significantly higher for $\mathrm{SO}$ compared with RO and LO. This indicates that the uptake of C18:2 cis-9,12 by the mammary gland was higher for SO compared with RO and LO. Differential uptake of FA by the mammary gland could be the result of changes in the FA composition of the different lipid fractions present in blood plasma. In this study, the total lipid fraction in blood plasma was analyzed, which includes cholesterol esters, phospholipids, triacyl- glycerols, and nonesterified FA. Because C18:2 cis-9,12 and $\mathrm{C} 18: 3$ cis-9,12,15 are preferentially incorporated in plasma cholesterol esters and phospholipids, whereas the bovine mammary gland primarily extracts FA from the triacylglycerols and nonesterified FA fractions in blood plasma (Loor et al., 2002), the transfer efficiency of these PUFA from diet to milk is generally low in dairy cows.

Because the different unsaturated FA sources were added to the diet as unprotected oils, an increase in ruminal biohydrogenation intermediates most likely occurred, as indicated by the rather high TFA isomer levels in milk. Some of these TFA can affect expression of several genes involved in lipid metabolism in the mammary gland. The trans-10, cis-12 CLA isomer has been identified as one of the major ruminal biohydrogenation intermediates responsible for the inhibition of milk fat synthesis in dairy cows (Baumgard et al., 2002). Studies on the mechanisms involved in the inhibition of milk fat synthesis revealed a coordinated downregulation of mammary gene expression of rate-limiting lipogenic enzymes, including lipoprotein lipase (LPL), acetylCoA carboxylase (ACC), fatty acid synthase (FAS), and SCD, following abomasal trans-10, cis-12 CLA infusion (Baumgard et al., 2002; Harvatine and Bauman, 2006) or diet-induced MFD (Peterson et al., 2003; Harvatine and Bauman, 2006). This inhibitory effect has been linked to decreased expression of transcription factor sterol regulatory element binding protein 1 (SREBP1) and proteins involved in the activation and distribution of SREBP1 toward the nucleus (Harvatine and Bauman, 2006). Indeed, milk trans-10, cis-12 CLA in our study was negatively correlated with milk fat content $\left(\mathrm{r}^{2}=0.54 ; P<0.001\right)$ and proportion of milk SMCFA $\left(\mathrm{r}^{2}=0.43 ; P<0.001\right)$. However, the amount of trans-10, cis-12 CLA in milk fat did not correlate with SCD1 mRNA expression $\left(r^{2}=0.001 ; P=0.88\right)$ or with that of SCD5 $\left(\mathrm{r}^{2}=0.009 ; P=0.48\right)$. Abomasal infu- 
Table 4. Milk fatty acid composition of cows fed the posttrial diet (POST) or the treatment diets supplemented with rapeseed oil (RO), soybean oil (SO), or linseed oil (LO), or a mixture of these 3 oils (MIX)

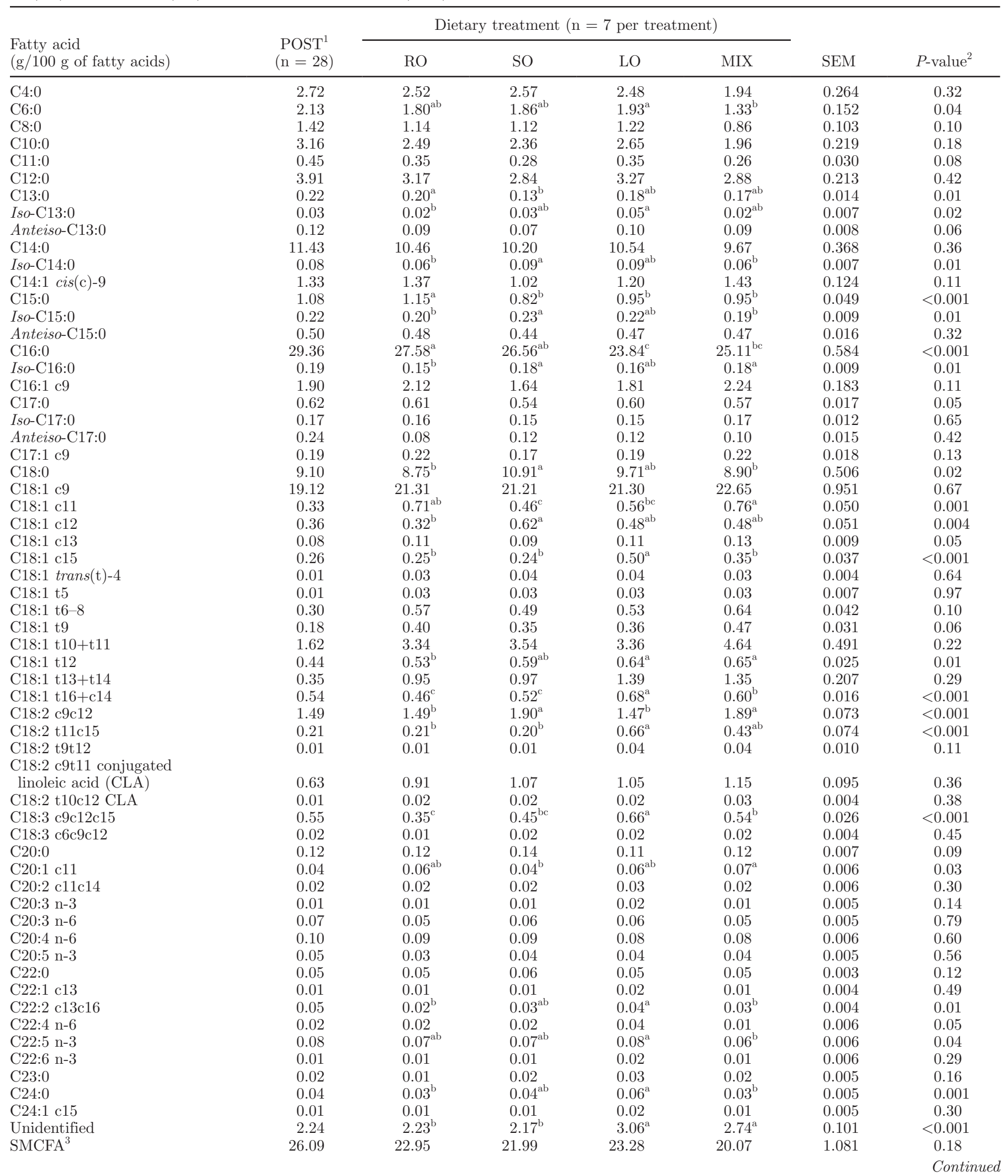


Table 4 (Continued). Milk fatty acid composition of cows fed the posttrial diet (POST) or the treatment diets supplemented with rapeseed oil (RO), soybean oil (SO), or linseed oil (LO), or a mixture of these 3 oils (MIX)

\begin{tabular}{|c|c|c|c|c|c|c|c|}
\hline $\begin{array}{l}\text { Fatty acid } \\
\text { (g/100 } \mathrm{g} \text { of fatty acids) }\end{array}$ & $\begin{array}{c}\mathrm{POST}^{1} \\
(\mathrm{n}=28)\end{array}$ & \multicolumn{4}{|c|}{ Dietary treatment $(\mathrm{n}=7$ per treatment) } & SEM & $P$-value \\
\hline $\mathrm{C} 16 \mathrm{FA}^{4}$ & 31.26 & $29.70^{\mathrm{a}}$ & $28.20^{\mathrm{a}}$ & $25.65^{\mathrm{b}}$ & $27.35^{\mathrm{ab}}$ & 0.651 & 0.002 \\
\hline $\mathrm{OBCFA}^{6}$ & 4.08 & $3.78^{\mathrm{a}}$ & $3.26^{\mathrm{b}}$ & $3.62^{\mathrm{ab}}$ & $3.47^{\mathrm{ab}}$ & 0.105 & 0.01 \\
\hline $\mathrm{SFA}^{7}$ & 67.35 & $61.68^{\mathrm{a}}$ & $61.78^{\mathrm{a}}$ & $59.31^{\mathrm{ab}}$ & $56.11^{\mathrm{b}}$ & 1.493 & 0.04 \\
\hline MUFA $^{8}$ & 27.09 & 32.78 & 32.04 & 33.29 & 36.75 & 1.295 & 0.08 \\
\hline \multicolumn{8}{|l|}{$\Delta^{9}$-desaturase index ${ }^{11}$} \\
\hline C14:1 c9 & 0.11 & 0.12 & 0.09 & 0.10 & 0.13 & 0.012 & 0.11 \\
\hline $\mathrm{C} 16: 1$ c9 & 0.07 & $0.07^{\mathrm{ab}}$ & $0.05^{\mathrm{b}}$ & $0.07^{\mathrm{ab}}$ & $0.08^{\mathrm{a}}$ & 0.006 & 0.02 \\
\hline C17:1 c9 & 0.25 & 0.26 & 0.23 & 0.24 & 0.28 & 0.016 & 0.18 \\
\hline C18:1 c9 & 0.69 & $0.71^{\mathrm{ab}}$ & $0.66^{\mathrm{b}}$ & $0.69^{\mathrm{ab}}$ & $0.72^{\mathrm{a}}$ & 0.014 & 0.04 \\
\hline
\end{tabular}

${ }^{\mathrm{a}-\mathrm{c}}$ Means within a row without a common superscript differ $(P<0.05)$.

${ }^{1}$ Values are shown for comparison only and were not included in the statistical analysis.

${ }^{2}$ Effect of treatment.

${ }^{3}$ Short- and medium-chain fatty acids: $\Sigma$ (C4:0, C6:0, C8:0, C10:0, C12:0, C14:0, C14:1 c9).

${ }^{4} \mathrm{C} 16$ fatty acids: $\Sigma(\mathrm{C} 16: 0, \mathrm{C} 16: 1 \mathrm{c} 9)$.

${ }^{5}$ Long-chain fatty acids: $\Sigma$ (fatty acids with 18 carbons or more).

${ }^{6}$ Odd- and branched-chain fatty acids $\Sigma$ (C11:0, C13:0, iso-C13:0, anteiso-C13:0, iso-C14:0, C15:0, iso-C15:0, anteiso-C15:0, iso-C16:0, C17:0, iso-C17:0, anteiso-C17:0, C17:1 c9).

${ }^{7}$ Saturated fatty acids: $\Sigma(\mathrm{C} 4: 0, \mathrm{C} 6: 0, \mathrm{C} 8: 0, \mathrm{C} 10: 0, \mathrm{C} 11: 0, \mathrm{C} 12: 0, \mathrm{C} 13: 0$, iso-C13:0, anteiso-C13:0, C14:0, iso-C14:0, C15:0, iso-C15:0, anteisoC15:0, C16:0, iso-C16:0, C17:0, iso-C17:0, anteiso-C17:0, C18:0, C20:0, C22:0, C23:0, C24:0).

${ }^{8}$ Monounsaturated fatty acids: $\Sigma$ (C14:1 c9, C16:1 c9, C17:1 c9, C18:1 c9, C18:1 c11, C18:1 c12, C18:1 c13, C18:1 c15, C18:1 t4, C18:1 t5, C18:1 t6-8, C18:1 t9, C18:1 t10+t11, C18:1 t12, C18:1 t13+t14, C18:1 t16+c14, C20:1 c11, C22:1 c13, C24:1 c15).

${ }^{9}$ Polyunsaturated fatty acids: $\Sigma$ (C18:2 c9c12, C18:2 t11c15, C18:2 t9t12, C18:2 c9t11 CLA, C18:2 t10c12 CLA, C18:3 c9c12c15, C18:3 c6c9c12, C20:2 c11c14, C20:3 n-3, C20:3 n-6, C20:4 n-6, C20:5 n-3, C22:2 c13c16, C22:4 n-6, C22:5 n-3, C22:6 n-3).

${ }^{10}$ Trans fatty acids: $\Sigma(\mathrm{C} 18: 1 \mathrm{t} 4, \mathrm{C} 18: 1 \mathrm{t} 5, \mathrm{C} 18: 1 \mathrm{t6}-8, \mathrm{C} 18: 1 \mathrm{t} 9, \mathrm{C} 18: 1 \mathrm{t} 10+\mathrm{t} 11, \mathrm{C} 18: 1 \mathrm{t} 12, \mathrm{C} 18: 1 \mathrm{t} 13+14, \mathrm{C} 18: 1 \mathrm{t} 16+\mathrm{c} 14, \mathrm{C} 18: 2 \mathrm{t} 11 \mathrm{c} 15, \mathrm{C} 18: 2$ t9t12, C18:2 c9t11 CLA, C18:2 t10c12 CLA).

${ }^{11} \Delta^{9}$-desaturase indices are calculated as $\Delta^{9}$-desaturase product divided by the sum of the $\Delta^{9}$-desaturase product and substrate.

sion with high doses of trans-10, cis-12 CLA, causing severe MFD, generally decreases desaturation indices serving as a proxy for SCD activity (Baumgard et al., 2001) and SCD expression (Baumgard et al., 2002). However, lower doses of trans-10, cis-12 CLA, causing mild MFD, typically do not affect the proxies for SCD activity (Peterson et al., 2002a; de Veth et al., 2004; Kay et al., 2007). Taken together, it is likely that in our study the unprotected dietary oil supplements did increase trans-10, cis-12 CLA production in the rumen, which probably inhibited milk fat synthesis to some extent, but this amount was not sufficient to significantly affect SCD expression.

The higher blood plasma proportion of C16:0 and C16:1 cis-9 for the RO diet, most likely reflected the higher concentrations of these FA in the RO diet. The higher proportion of $\mathrm{C} 18: 2$ trans-11, cis-15 in blood plasma observed in cows fed the LO diet is in agreement with previous studies, demonstrating that C18:2 trans-11, cis-15 is the primary biohydrogenation intermediate produced in the rumen from C18:3 cis-9,12,15 (Harfoot and Hazlewood, 1988; Loor et al., 2005).
In our study, cows on the $\mathrm{SO}$ diet showed a significant lower SCD1 expression (55\% reduction) in the mammary gland, compared with cows that received the $\mathrm{RO}$ or LO diet. In rodents, PUFA supplementation, especially of the n-3 and n- 6 series, results in suppression of hepatic SCD1 expression, whereas SFA and MUFA have no or little effect (Ntambi, 1999). Moreover, Singh et al. (2004) found that dietary supplementation of safflower oil, which is high in C18:2 cis-9,12, decreased SCD1 mRNA levels and total SCD activity in the mammary gland of lactating mice. In goats, however, Bernard et al. (2005b) reported that dietary soybean supplementation ( $\pm 23 \mathrm{~g}$ of $\mathrm{C} 18: 2$ cis-9,12 per $\mathrm{kg}$ of $\mathrm{DM}$ ) decreased SCD1 expression in subcutaneous adipose tissue, but not in the mammary gland, indicating that the mammary gland might be less sensitive to dietary manipulation by PUFA compared with subcutaneous adipose tissue. In addition, it was shown by Murrieta et al. (2006) that feeding high-linoleate safflower seeds $( \pm 18$ $\mathrm{g}$ of $\mathrm{C} 18: 2$ cis-9,12 per $\mathrm{kg}$ of $\mathrm{DM}$ ) to lactating beef cows did not affect abundance of SCD1 mRNA in the mammary gland. 
a)

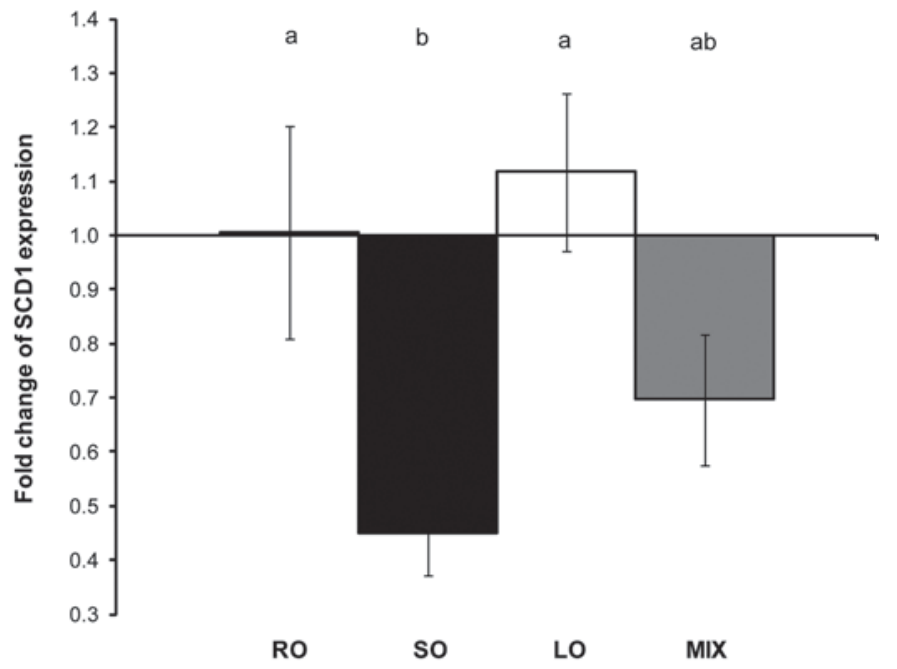

b)

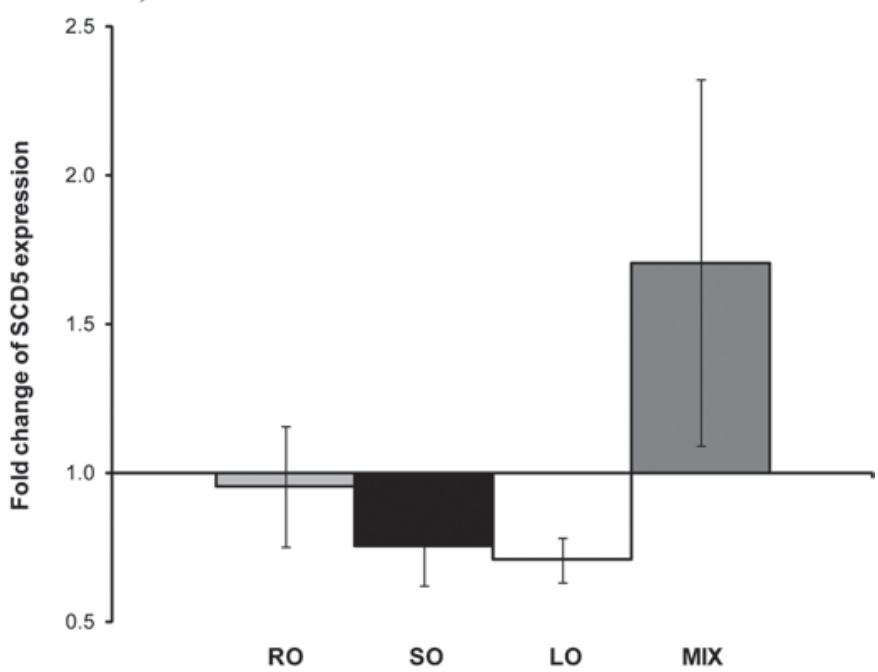

Figure 1. Patterns of mammary stearoyl-CoA desaturase (SCD)-1 (a) as well as SCD5 (b) mRNA expression in cows fed diets supplemented with rapeseed oil (RO), soybean oil (SO), or linseed oil (LO), or a mixture of these 3 oils (MIX). Mammary gene expression was determined with real-time PCR and expressed as fold change compared with the corresponding control values. Vertical lines represent the standard error of the mean, and treatments without a common letter differ $(P<0.05)$. For SO and LO, $\mathrm{n}=7$, and for RO and MIX, $\mathrm{n}=6$.

Contrary to the results with SO, we found no differences in mammary SCD1 mRNA levels between cows receiving the RO, LO, or MIX diets. This is in agreement with Delbecchi et al. (2001), who found no differences in mammary SCD1 expression in dairy cows in response to dietary supplementation of protected or unprotected canola oil ( $\pm 38 \mathrm{~g}$ of $\mathrm{C} 18: 1$ cis-9 per $\mathrm{kg}$ of DM). Moreover, data from Enjalbert et al. (1998) showed no significant effect on mammary gland desaturation rate of $\mathrm{C} 18: 0$ in lactating Holstein cows, when a)

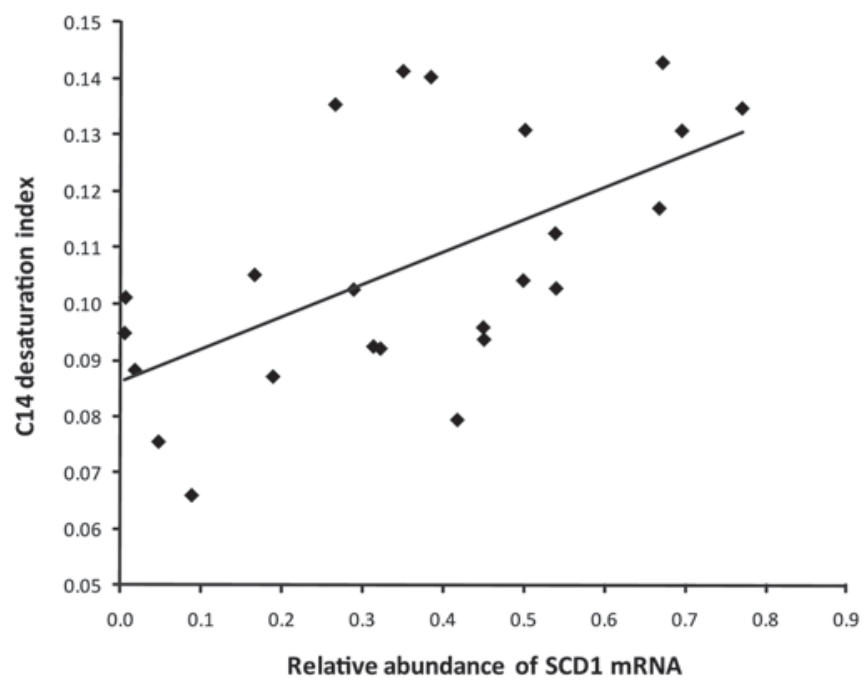

b)

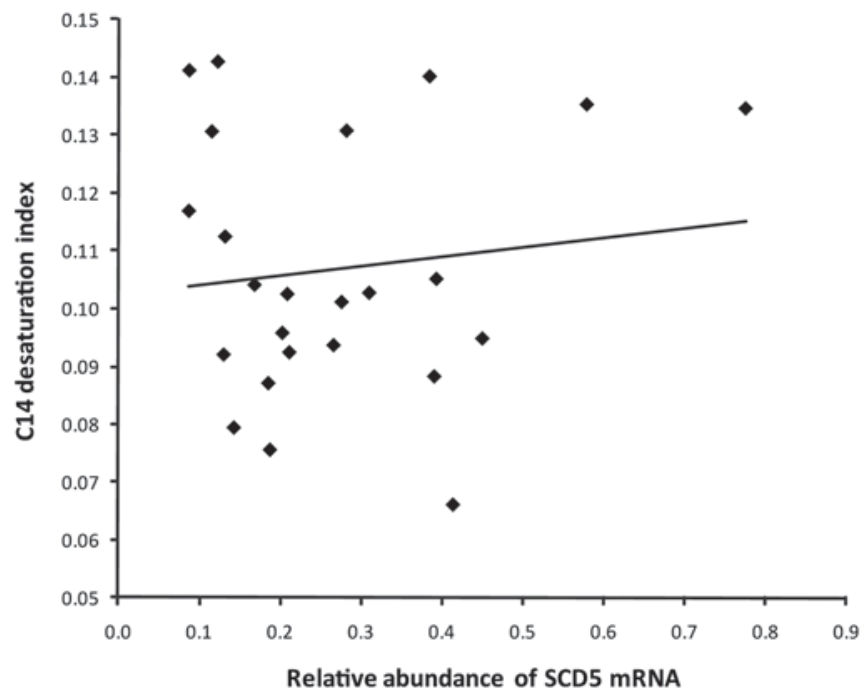

Figure 2. Correlation between the $\mathrm{C} 14$ desaturation index and the relative abundance of mammary stearoyl-CoA desaturase (SCD)-1 mRNA (a) or SCD5 mRNA (b) of cows in the treatment period $(\mathrm{n}=$ 24). The desaturation indices were calculated from milk fatty acids as follows: C14:1 cis-9/(C14:1 cis-9 + C14:0). For SCD1, the C14 index $=0.086( \pm 0.007)+0.058( \pm 0.017) \times \mathrm{SCD} 1$ expression; $\mathrm{r}^{2}=0.35 ; P$ $=0.002 ;$ for SCD5, the C14 index $=0.102( \pm 0.009)+0.016( \pm 0.028)$ $\times$ SCD5 expression; $\mathrm{r}^{2}=0.02 ; P=0.57$.

C18:1 cis-9 was duodenally infused. In goats, however, dietary supplementation with oleic sunflower oil or formaldehyde-treated linseed reduced SCD1 expression in the mammary gland $(P=0.07$ and $P<0.05$, respectively; Bernard et al., 2005a). These inconsistent results could be caused by species-specific differences in the regulation of SCD1 gene expression, or because we used a lower level of FA supplementation (12 g of C18:1 cis-9 or $\mathrm{C} 18: 3$ cis-9,12,15 per $\mathrm{kg}$ of $\mathrm{DM}$ in our 
study versus $30 \mathrm{~g}$ of $\mathrm{C} 18: 1$ cis- 9 per $\mathrm{kg}$ of $\mathrm{DM}$ or $25 \mathrm{~g}$ of C18:3 cis-9,12,15 per $\mathrm{kg}$ of DM in the study of Bernard et al., 2005a).

Mammary SCD5 expression did not differ between the 4 dietary treatments, indicating that SCD5 and SCD1 are differently regulated. In line with this, it was demonstrated recently that mammary SCD1 mRNA expression tended to be reduced in dairy cows by intravenous infusion of trans-10, cis-12 CLA, whereas no effect on the expression of mammary SCD5 was observed (Gervais et al., 2009). The knowledge that SCD5 lacks N-terminal PEST sequences [rich in Pro (P), Glu (E), Ser (S), and Thr (T)] typically found in SCD1 (Lengi and Corl, 2007), which are considered to be a signal for protein degradation (Rechsteiner and Rogers, 1996), may suggest that SCD5 exhibits a higher protein stability than SCD1, and that SCD5 might be less sensitive to nutritional regulation at the mRNA level than SCD1. This is in accordance with our observation that the mRNA abundance for SCD1 was much higher $\left(>10^{3}\right)$ than that for SCD5 in the mammary tissue biopsies. In addition, the fact that SCD5 is abundantly expressed in brain, a tissue enriched in PUFA, may suggest that the expression of transcripts for SCD5 is less sensitive to PUFA than that for SCD1 (Lengi and Corl, 2007). Further studies are needed to provide compelling evidence that SCD1 and SCD5 are differentially regulated at the transcriptional or protein level in the bovine mammary gland.

The higher proportion of C16:0 in milk fat for the RO diet was most likely caused by the somewhat higher proportion of $\mathrm{C} 16: 0$ in the $\mathrm{RO}$ diet. In contrast to our expectations, the proportion of C18:1 cis-9 in milk fat was not higher for the RO diet, although the proportion of C18:1 cis-9 in blood plasma was significantly higher for RO compared with the other diets. A lower SCD activity is not supported by our findings, because mRNA levels of SCD1 and SCD5 as well as desaturation indices in milk for the RO diet did not differ compared with LO and MIX. Therefore, we suggest that the uptake of C18:1 cis-9 by the mammary gland is somewhat low or that the absorbed C18:1 cis-9 is utilized for processes other than milk fat synthesis.

Several pairs of FA that represent a product-substrate relationship for SCD are present in milk fat and are frequently used to estimate in vivo SCD activity within the mammary gland. The desaturase indices typically used are the $\mathrm{C} 14, \mathrm{C} 16, \mathrm{C} 17$, and $\mathrm{C} 18$ indices and the cis-9, trans-11 CLA index. The C14 index is considered the best indicator of SCD activity, because most of the C14:0 present in milk generally originates from de novo FA synthesis in the mammary gland, and desaturation of C14:0 is the major source of C14:1 cis-9 (Peterson et al., 2002b; Lock and Garnsworthy, 2003;
Bernard et al., 2008). Indeed, blood plasma levels of C14:0 were low $(0.6 \pm 0.04 \mathrm{~g} / 100 \mathrm{~g}$ of $\mathrm{FA})$ and $\mathrm{C} 14: 1$ cis-9 was not detected. In contrast, the absorption of various $\mathrm{C} 16$ and $\mathrm{C} 18 \mathrm{FA}$ from the duodenum and from mobilized adipose tissue can be significant (Glasser et al., 2008), and proportions of $\mathrm{C} 16: 1$ cis-9, C17:1 cis9, and in particular C18:1 cis-9 in blood plasma FA were substantial. Because no distinction between C18:1 trans-10 and trans-11 could be made in our study, the cis-9, trans-11 CLA index was not calculated. The SO diet in our study, which caused a downregulation of SCD1 mRNA compared with the other unprotected oil supplements, indeed resulted in the lowest values for the $\mathrm{C} 16$ and $\mathrm{C} 18$ desaturation indices. This suggests that the lower SCD1 expression for the SO diet caused a reduction in SCD1 activity in the mammary gland. Positive, but not strong, relationships were found between SCD1 mRNA levels and the 4 desaturase indices. Feng et al. (2007) reported a significant relationship between the C14 desaturase index and relative abundance of SCD mRNA in milk somatic cells from dairy cows, indicating that both produce similar estimates of relative SCD activity in the mammary gland. Also in goats, moderate relationships were found among SCD mRNA levels, in vitro SCD activity, and milk proxy ratios for SCD activity (Bernard et al., 2005a). However, some findings indicate that desaturase indices do not always reflect actual SCD activity in bovine adipose tissue (Archibeque et al., 2005) or in the bovine mammary gland (Bionaz and Loor, 2008). Differences between the mammary SCD mRNA levels and desaturase indices calculated from milk FA could be due to effects at the protein level of SCD or because SCD1 has additional physiological functions such as the synthesis of phospholipids (Scaglia and Igal, 2005).

Contrary to results for SCD1, we found no relationship between SCD5 mRNA abundance and the 4 desaturase indices. Together with the relatively low mRNA levels of SCD5, our data suggest that the contribution of mammary SCD5 to generate milk $\Delta^{9}$-unsaturated FA is relatively small. However, further research on SCD5 is necessary to determine its role in $\Delta^{9}$-desaturation of milk FA in the bovine mammary gland.

\section{CONCLUSIONS}

This study showed that mammary SCD1 mRNA expression in dairy cows was significantly downregulated by feeding unprotected soybean oil compared with rapeseed oil or linseed oil. In addition, SCD5 expression was not significantly affected by the 4 dietary treatments. This inhibitory effect on mammary SCD1 expression by feeding unprotected soybean oil was partially reflected by the lower desaturase indices calculated from milk 
FA. Mammary expression of SCD1 transcripts appeared to be more sensitive to dietary supply of C18:2 cis-9,12 than to that of $\mathrm{C} 18: 1$ cis-9 or $\mathrm{C} 18: 3$ cis-9,12,15. Our data also support the idea that SCD1 and SCD5 expression in the bovine mammary gland respond differentially to dietary FA.

\section{ACKNOWLEDGMENTS}

Financial support of SenterNovem, The Hague, the Netherlands; FrieslandCampina, Amersfoort, the Netherlands; Cehave Landbouwbelang, Veghel, the Netherlands; and Barenbrug Holland, Nijmegen, the Netherlands is gratefully acknowledged. Also, the authors thank Aura Widjaja, Paul Kroon, Dirk Anjema and Leo Kruijt (Wageningen UR Livestock Research, Lelystad, the Netherlands) for their assistance.

\section{REFERENCES}

Abrahamse, P. A., J. Dijkstra, B. Vlaeminck, and S. Tamminga. 2008a. Frequent allocation of rotationally grazed dairy cows changes grazing behavior and improves productivity. J. Dairy Sci. 91:20332045.

Abrahamse, P. A., B. Vlaeminck, S. Tamminga, and J. Dijkstra. 2008b. The effect of silage and concentrate type on intake behavior, rumen function, and milk production in dairy cows in early and late lactation. J. Dairy Sci. 91:4778-4792.

Ahnadi, C. E., N. Beswick, L. Delbecchi, J. J. Kennelly, and P. Lacasse. 2002. Addition of fish oil to diets for dairy cows. II: Effects on milk fat and gene expression of mammary lipogenic enzymes. J. Dairy Res. 69:521-531.

Archibeque, S. L., D. K. Lunt, C. D. Gilbert, R. K. Tume, and S. B. Smith. 2005. Fatty acid indices of stearoyl-CoA desaturase do not reflect actual stearoyl-CoA desaturase enzyme activities in adipose tissues of beef steers finished with corn-, flaxseed-, or sorghumbased diets. J. Anim. Sci. 83:1153-1166.

Baumgard, L. H., E. Matitashvili, B. A. Corl, D. A. Dwyer, and D. E. Bauman. 2002. Trans-10, cis-12 conjugated linoleic acid decreases lipogenic rates and expression of genes involved in milk lipid synthesis in dairy cows. J. Dairy Sci. 85:2155-2163.

Baumgard, L. H., J. K. Sangster, and D. E. Bauman. 2001. Milk fat synthesis in dairy cows is progressively reduced by increasing supplemental amounts of trans-10, cis-12 conjugated linoleic acid (CLA). J. Nutr. 131:1764-1769.

Bernard, L., C. Leroux, M. Bonnet, J. Rouel, P. Martin, and Y. Chilliard. 2005b. Expression and nutritional regulation of lipogenic genes in mammary gland and adipose tissues of lactating goats. J. Dairy Res. 72:250-255.

Bernard, L., C. Leroux, and Y. Chilliard. 2008. Expression and nutritional regulation of lipogenic genes in the ruminant lactating mammary gland. Adv. Exp. Med. Biol. 606:67-108.

Bernard, L., J. Rouel, C. Leroux, A. Ferlay, Y. Faulconnier, P. Legrand, and Y. Chilliard. 2005a. Mammary lipid metabolism and milk fatty acid secretion in alpine goats fed vegetable lipids. J. Dairy Sci. 88:1478-1489.

Bionaz, M., and J. J. Loor. 2008. Gene networks driving bovine milk fat synthesis during the lactation cycle. BMC Genomics 9:366.

Cruz-Hernandez, C., J. K. G. Kramer, J. J. Kennelly, D. R. Glimm, B. M. Sorensen, E. K. Okine, L. A. Goonewardene, and R. J. Weselake. 2007. Evaluating the conjugated linoleic acid and trans-18:1 isomers in milk fat of dairy cows fed increasing amounts of sunflower oil and a constant level of fish oil. J. Dairy Sci. 90:37863801 . de Veth, M. J., J. M. Griinari, A. M. Pfeiffer, and D. E. Bauman. 2004 Effect of CLA on milk fat synthesis in dairy cows: Comparison of inhibition by methyl esters and free fatty acids, and relationships among studies. Lipids 39:365-372.

Delbecchi, L., C. E. Ahnadi, J. J. Kennelly, and P. Lacasse. 2001. Milk fatty acid composition and mammary lipid metabolism in Holstein cows fed protected or unprotected canola seeds. J. Dairy Sci. $84: 1375-1381$.

Enjalbert, F., M.-C. Nicot, C. Bayourthe, and R. Moncoulon. 1998. Duodenal infusions of palmitic, stearic or oleic acids differently affect mammary gland metabolism of fatty acids in lactating dairy cows. J. Nutr. 128:1525-1532.

Farr, V. C., K. Stelwagen, L. R. Cate, A. J. Molenaar, T. B. McFadden, and S. R. Davis. 1996. An improved method for the routine biopsy of bovine mammary tissue. J. Dairy Sci. 79:543-549.

Feng, S., A. M. Salter, T. Parr, and P. C. Garnsworthy. 2007. Extraction and quantitative analysis of stearoyl-CoA desaturase mRNA from dairy cow milk somatic cells. J. Dairy Sci. 90:4128-4136.

Folch, J., M. Lees, and H. Sloane Stanley. 1957. A simple method for the isolation and purification of total lipids from animal tissues. J. Biol. Chem. 226:497-509.

Gervais, R., J. W. McFadden, A. J. Lengi, B. A. Corl, and P. Y. Chouinard. 2009. Effects of intravenous infusion of trans-10, cis-12 18:2 on mammary lipid metabolism in lactating dairy cows. J. Dairy Sci. 92:5167-5177.

Glasser, F., A. Ferlay, M. Doreau, P. Schmidely, D. Sauvant, and Y. Chilliard. 2008. Long-chain fatty acid metabolism in dairy cows: A meta-analysis of milk fatty acid yield in relation to duodenal flows and de novo synthesis. J. Dairy Sci. 91:2771-2785.

Goelema, J. O., M. A. M. Spreeuwenberg, G. Hof, A. F. B. van der Poel, and S. Tamminga. 1998. Effect of pressure toasting on the rumen degradability and intestinal digestibility of whole and broken peas, lupins and faba beans and a mixture of these feedstuffs. Anim. Feed Sci. Technol. 76:35-50.

Harfoot, C., and G. Hazlewood. 1988. Lipid metabolism in the rumen. Pages 285-322 in The Rumen Microbial Ecosystem. P. N. Hobson, ed. Elsevier, London, UK.

Harvatine, K. J., and D. E. Bauman. 2006. SREBP1 and thyroid hormone responsive spot 14 (S14) are involved in the regulation of bovine mammary lipid synthesis during diet-induced milk fat depression and treatment with CLA. J. Nutr. 136:2468-2474.

Heck, J. M., H. J. F. van Valenberg, J. Dijkstra, and A. C. M. van Hooijdonk. 2009. Seasonal variation in the Dutch bovine raw milk composition. J. Dairy Sci. 92:4745-4755.

ISO. 1999a. Animal Feeding Stuffs. Determination of moisture and other volatile matter content. ISO 6496:1999. International Organization for Standardization, Geneva, Switzerland.

ISO. 1999b. Animal Feeding Stuffs. Determination of fat content. ISO 6492:1999. International Organization for Standardization, Geneva, Switzerland.

ISO. 1999c. Whole milk. Determination of milk fat, protein and lactose content - Guidance on the operation of mid-infrared instruments. ISO 9622:1999. International Organization for Standardization, Geneva, Switzerland.

ISO. 2002. Animal Feeding Stuffs. Determination of crude ash. ISO 5984:2002. International Organization for Standardization, Geneva, Switzerland.

ISO. 2004. Animal Feeding Stuffs. Enzymatic determination of total starch content. ISO 15914:2004. International Organization for Standardization, Geneva, Switzerland.

ISO. 2005. Animal Feeding Stuffs. Determination of nitrogen content and calculation of crude protein content-Kjeldahl method. ISO 5983:1997. International Organization for Standardization, Geneva, Switzerland.

Kay, J. K., T. R. Mackle, D. E. Bauman, N. A. Thomson, and L. H Baumgard. 2007. Effects of a supplement containing trans-10, cis12 conjugated linoleic acid on bioenergetic and milk production parameters in grazing dairy cows offered ad libitum or restricted pasture. J. Dairy Sci. 90:721-730.

Kelsey, J. A., B. A. Corl, R. J. Collier, and D. E. Bauman. 2003. The effect of breed, parity, and stage of lactation on conjugated 
linoleic acid (CLA) in milk fat from dairy cows. J. Dairy Sci. $86: 2588-2597$.

Khan, N. A., J. W. Cone, and W. H. Hendriks. 2009. Stability of fatty acids in grass and maize silages after exposure to air during the feed out period. Anim. Feed Sci. Technol. 154:183-192.

Lengi, A. J., and B. A. Corl. 2007. Identification and characterization of a novel bovine stearoyl-CoA desaturase isoform with homology to human SCD5. Lipids 42:499-508.

Lin, X., J. J. Loor, and J. H. Herbein. 2004. Trans-10, cis-12 18:2 is a more potent inhibitor of de novo fatty acid synthesis and desaturation than cis-9, trans-11 18:2 in the mammary gland of lactating mice. J. Nutr. 134:1362-1368.

Lock, A. L., and D. E. Bauman. 2004. Modifying milk fat composition of dairy cows to enhance fatty acids beneficial to human health. Lipids 39:1197-1206.

Lock, A. L., and P. C. Garnsworthy. 2003. Seasonal variation in milk conjugated linoleic acid and $\Delta 9$-desaturase activity in dairy cows. Livest. Prod. Sci. 79:47-59.

Loor, J. J., J. H. Herbein, and C. E. Polan. 2002. Trans 18:1 and 18:2 isomers in blood plasma and milk fat of grazing cows fed a grain supplement containing solvent-extracted or mechanically extracted soybean meal. J. Dairy Sci. 85:1197-1207.

Loor, J. J., K. Ueda, A. Ferlay, Y. Chilliard, and M. Doreau. 2004. Biohydrogenation, duodenal flow, and intestinal digestibility of trans fatty acids and conjugated linoleic acids in response to dietary forage:concentrate ratio and linseed oil in dairy cows. J. Dairy Sci. 87:2472-2485.

Loor, J. J., K. Ueda, A. Ferlay, Y. Chilliard, and M. Doreau. 2005. Intestinal flow and digestibility of trans fatty acids and conjugated linoleic acids (CLA) in dairy cows fed a high-concentrate diet supplemented with fish oil, linseed oil, or sunflower oil. Anim. Feed Sci. Technol. 119:203-225.

McDonald, T. M., and J. E. Kinsella. 1973. Stearyl-CoA desaturase of bovine mammary microsomes. Arch. Biochem. Biophys. 156:223231.

Mensink, R. P., P. L. Zock, A. D. M. Kester, and M. B. Katan. 2003. Effects of dietary fatty acids and carbohydrates on the ratio of serum total to HDL cholesterol and on serum lipids and apolipoproteins: A meta-analysis of 60 controlled trials. Am. J. Clin. Nutr. 77:1146-1155.

Metcalfe, L. D., A. A. Schimitz, and J. R. Pelka. 1966. Rapid preparation of fatty acid esters from lipids for gas chromatographic analysis. Anal. Chem. 38:514-515.

Murrieta, C. M., B. W. Hess, E. J. Scholljegerdes, T. E. Engle, K. L. Hossner, G. E. Moss, and D. C. Rule. 2006. Evaluation of milk somatic cells as a source of mRNA for study of lipogenesis in the mammary gland of lactating beef cows supplemented with dietary high-linoleate safflower seeds. J. Anim. Sci. 84:2399-2405.

Ntambi, J. M. 1999. Regulation of stearoyl-CoA desaturase by polyunsaturated fatty acids and cholesterol. J. Lipid Res. 40:1549 1558 .
Ntambi, J. M., and M. Miyazaki. 2004. Regulation of stearoyl-CoA desaturases and role in metabolism. Prog. Lipid Res. 43:91-104.

Parillo, M., and G. Riccardi. 2004. Diet composition and the risk of type 2 diabetes: Epidemiological and clinical evidence. Br. J. Nutr. 92:7-19.

Penning, P. D. 2004. Herbage Intake Handbook. 2nd ed. The British Grassland Society, Reading, UK.

Peterson, D. G., L. H. Baumgard, and D. E. Bauman. 2002a. Short communication: Milk fat response to low doses of trans-10, cis-12 conjugated linoleic acid (CLA). J. Dairy Sci. 85:1764-1766.

Peterson, D. G.. J. A. Kelsey, and D. E. Bauman. 2002b. Analysis of variation in cis-9, trans-11 conjugated linoleic acid (CLA) in milk fat of dairy cows. J. Dairy Sci. 85:2164-2172.

Peterson, D. G., E. A. Matitashvili, and D. E. Bauman. 2003. Diet-induced milk fat depression in dairy cows results in increased trans-10, cis-12 CLA in milk fat and coordinate suppression of mRNA abundance for mammary enzymes involved in milk fat synthesis. J. Nutr. 133:3098-3102.

Pfaffl, M. W. 2001. A new mathematical model for relative quantification in real-time RT-PCR. Nucleic Acids Res. 29:e45.

Rechsteiner, M., and S. W. Rogers. 1996. PEST sequences and regulation by proteolysis. Trends Biochem. Sci. 21:267-271.

Scaglia, N., and R. A. Igal. 2005. Stearoyl-CoA desaturase is involved in the control of proliferation, anchorage-independent growth, and survival in human transformed cells. J. Biol. Chem. 280:2533925349 .

Shingfield, K. J., C. K. Reynolds, G. Hervas, J. M. Griinari, A. S Grandison, and D. E. Beever. 2006. Examination of the persistency of milk fatty acid composition responses to fish oil and sunflower oil in the diet of dairy cows. J. Dairy Sci. 89:714-732.

Singh, K., D. G. Hartley, T. B. McFadden, and D. D. Mackenzie. 2004. Dietary fat regulates mammary stearoyl-CoA desaturase expression and activity in lactating mice. J. Dairy Res. 71:1-6.

van Knegsel, A. T. M., H. van den Brand, J. Dijkstra, W. M. van Straalen, M. J. W. Heetkamp, S. Tamminga, and B. Kemp. 2007. Dietary energy source in dairy cows in early lactation: Energy partitioning and milk composition. J. Dairy Sci. 90:1467-1476.

Van Soest, P. J. 1973. Collaborative study of acid-detergent fibre and lignin. J. Assoc. Off. Anal. Chem. 56:781-784.

Van Soest, P. J., J. B. Robertson, and B. A. Lewis. 1991. Methods for dietary fiber, neutral detergent fiber, and non-starch polysaccharides in relation to animal nutrition. J. Dairy Sci. 74:3583-3597.

Wang, J., L. Yu, R. E. Schmidt, C. Su, X. Huang, K. Gould, and G. Cao. 2005. Characterization of HSCD5, a novel human stearoylCoA desaturase unique to primates. Biochem. Biophys. Res. Commun. 332:735-742. 